\section{Revidert grunnbok om rusmidler}

Fekjær HO

Rus

Bruk, motiver, skader, behandling, forebygging, historie. 3. utg. 423 s, tab, ill. Oslo: Gyldendal Akademisk, 2009. Pris NOK 448

ISBN 978-82-05-39068-3

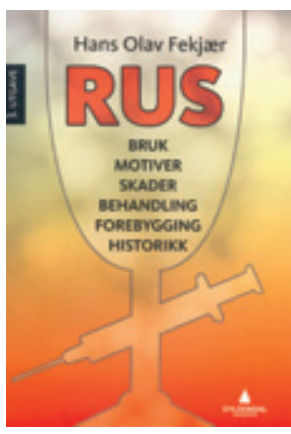

Den tredje utgaven av Hans Olav Fekjærs bok er noe endret siden forrige utgave. Dette er også den eneste norske boken som søker å dekke hele feltet rus. Det er derfor en viktig bok, en bok vi må være oppmerksom på.

Dette er bakgrunnen for denne anmeldelsen.

Det å skrive en slik lærebok er et imponerende arbeid for en enkelt person. Fekjær er kunnskapsrik, men ikke engang Fekjær kan like mye om alt. Fremstillingen har derfor mange styrker, men også svakheter. Først noe om styrkene. Gjennom 42 enkeltkapitler dekker forfatteren et bredt utvalg av temaer knyttet til rusmiddelfeltet. Fra ulike faglige ståsteder belyses historie, begreper, forklaringsmodeller, behandling, forebygging og skadevirkninger av rusmiddelbruk. Her får man innblikk i sentrale teorier og ikke minst et slags overblikk over feltet som gjør boken anvendbar i mange sammenhenger; til videre- og etterutdanning for mange faggrupper. Fekjær formidler godt de mytene som omgir rusmidlers virkning og konsekvensene rusmiddelbruk har for vårt samfunn. Her finnes materiale å bryne våre fastlåste oppfatninger på! I tillegg skriver han både underholdende og spennende. Hans argumenter blir til dels bygd opp med anekdoter, som gode historier. Når han i tillegg ofte er både polemisk og uakademisk i sin stil bidrar dette til reell leseglede.

Men heri ligger også bokens problem. På flere steder er det som formidles ikke godt nok underbygd. Eller, litteraturen leses skjevt, slik at den brukes til å fremheve forfatterens egne meninger fremfor å belyse saken fra flere sider. Det er jo en forfatters rett (og for så vidt plikt) å komme med sitt verdensbilde gjennom sin publikasjon, men dette blir innimellom for subjektivt! Noen eksempler. Kan vi fullstendig avvise psykologisk avhengighet som tautologisk myte? Er det ikke for lettvint å utelate det viktige og store fagfeltet biologisk kunnskap om rusmiddelavhengighet? Blir det ikke nesten parodisk når man hevder at de ulike rusmidlene ikke har noen bestemt virkning? At alt har med placebovirkningen å gjøre? Det er dessverre for mange slike eksempler.

For Fekjær er denne subjektiviteten sikkert et bevisst valg. Han har nok ønsket å bruke denne anledningen til å fremheve sine synspunkter innenfor et felt han har god kunnskap om. Men dette blir hovedproblemet. Dette balanserer hele tiden på kanten av hva som kan aksepteres fra en bok som skal fungere som grunnbok i et fagfelt.

Men etter en totalvurdering lander nok Fekjær på rett side. Til tross for svakhetene bidrar hans kunnskaper på mange felter til at dette blir en nyttig bok. Det er bare å håpe at han i neste utgave forsøker seg på en bedre balanse mellom egne og andres meninger.

\section{Jørgen G. Bramness}

Senter for rus og avhengighetsforskning Universitetet i Oslo

\section{Skarpere lys på arbeidsevne}

Nordenfelt L.

The concept of work ability

234 s. Brüssel: Peter Lang Publishing, 2008.

Pris EUR 30

ISBN 978-90-5201-450-0

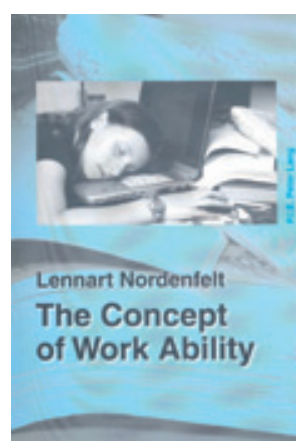

Det sitter mange leger - $\mathrm{i}$ trygdevesen og helsetjeneste - og vurderer pasientenes evne til å arbeide. De er blitt spurt om hvor mye nedsatt arbeidsevnen er, om nedsettelsen beror på sykdom, og prognosen. Vanskelige spørsmål synes de

fleste, og verre blir det når begrepene har ulik betydning i ulike sammenhenger. Denne boken av den svenske filosofen Lennart Nordenfelt er et forsøk på avklaring ved hjelp av begrepsanalyse. Hva mener vi med arbeidsevne og hva burde vi mene?

Nordenfelts arbeider er internasjonalt kjent innenfor to områder: handlingsteori og begrepsanalyser av helse, sykdom og funksjonsevne. Innholdet er basert på hans erfaringer innenfor begge områdene og er presentert i fire deler: Arbeid og arbeidsevne i samtidslitteraturen, En handlingsteoretisk tilnærming til arbeidsevne, Arbeidsevne og medisinske tilstander, Om vurdering av arbeidsevne.

Innledningsvis gir forfatteren en oversikt over trygdemedisinske metoder for vurdering av arbeidsevne. Han tar også opp bruken av arbeidsevnebegrepet i profesjonsutdanning og lønnsforhandlinger. Denne bredden i tilnærmingen er tiltalende og spennende. For en trygdemedisiner er avsnittet om forskningen til Strauss og medarbeidere spesielt interessant, med deres betoning av «trøstearbeid» (comfort work) og «følelsesarbeid» (sentimental work) som vanlige og krevende deler av mange jobber.
I den påfølgende delen legges først det teoretiske grunnlaget for analysene, deretter drøftes de typer kompetanse og andre evner som bør inngå i arbeidsevne. Interessant er Nordenfelts tydelige standpunkt at vilje og motivasjon ikke skal regnes som en evne, men er en forutsetning for all handling, unntatt under spesielle omstendigheter, f.eks. ved dyp depresjon.

I delen om forholdet mellom arbeidsevne og helse/sykdom viser forfatteren til vanskene med å enes om en felles teoretisk definisjon av sykdom som kriterium for trygdeytelser. Han anbefaler derfor pragmatiske løsninger $\mathrm{og}$ foreslår og beskriver et holistisk sykdomsbegrep. Han drøfter hvilke forutsetninger som må være til stede. I den siste delen gis kommentarer til ulike måter å vurdere arbeidsevne på. Nordenfelt tviler på mulighetene til å gjøre en rettferdig arbeidsevnevurdering utelukkende basert på skjemaer. Han mener at evnen må vurderes individuelt og må relatere individets evner til rådende krav og omstendigheter.

Dette er en spennende bok som drøfter viktige trygdemedisinske begreper. På markedet finnes få alternativer. Boken egner seg for praktikere, forskere og politikere. Språket er klart og tydelig. Selv om forfatteren tar opp filosofiske temaer er stoffet lett tilgjengelig for en vanlig leser. De vanskelige spørsmålene som må besvares ved enhver arbeidsevnevurdering, får ny belysning.

\section{Søren Brage}

Arbeids-og velferdsdirektoratet Oslo

\section{Lærebok i bioanalytisk kjemi}

Gault VA, McClenaghan NH. Understanding bioanalytical chemistry Principles and applications. $290 \mathrm{~s}$, tab, ill. Chichester: Wiley-Blackwell, 2009. Pris GBP 28 ISBN 978-0-470-02907-7

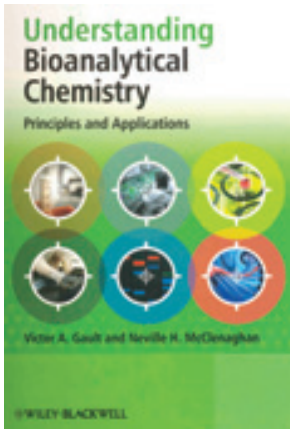

Forfatterne sier i forordet at målgruppen er studenter i biologiske fag og helsefagene som ikke er fortrolige med kjemifaget. I tillegg sier de at disse studentene ikke ser relevansen til eget studium. Dette har vært årsaken til at

forfatterne har endret måten de underviser bioanalytisk kjemi på. Det er utstrakt bruk av eksempler, men noen av dem er litt søkt og noen av dem er foreldet i forhold til diagnostiske analyser i dag.

De 272 sidene er inndelt i 12 kapitler av overkommelig størrelse, i tillegg er det et 